\title{
An Institutional Theory of Tax Non- Compliance in Bulgaria: a Tax Morale Approach
}

\section{Colin Williams*}

\begin{abstract}
To explain tax non-compliance, the dominant approach has been to view noncompliance as a rational economic decision taken when the benefits outweigh the costs. However, many remain compliant even when non-compliance is the rational economic decision. The outcome has been the emergence of a new tax morale approach. Grounded in institutional theory, this asserts that formal institutional failings lead to an asymmetry between the laws and regulations of a society's formal institutions and the beliefs of the population that constitute its informal institutions. The greater is this asymmetry (measured by the level of tax morale), the greater is the prevalence of tax non-compliance. Until now, studies have analysed the tax morale of citizens. This paper evaluates the tax morale of entrepreneurs and identifies the formal institutional failings that lead to lower tax morale among entrepreneurs. Reporting 456 face-to-face interviews with a nationally representative sample of entrepreneurs in Bulgaria, it is revealed not only that the tax morale of entrepreneurs varies by sector and firm size, but also that the formal institutional failings significantly
\end{abstract}

associated with low tax morale include a perceived lack of tax fairness, corruption and political instability. The implications for theory and policy are then discussed.

Keywords: informal economy, shadow economy, tax evasion, tax morale, entrepreneurship, institutional theory, Bulgaria.

JEL Code: H26, J46, K42, O17, P37

\section{Introduction}

The dominant explanation of tax noncompliance for some five decades has been to view non-compliance as a rational economic decision taken when the benefits are greater than the expected costs of being detected and penalised (Allingham and Sandmo, 1972). However, there has emerged a recognition that many remain compliant even when the benefits outweigh the costs, and the rational economic decision would be for them to be non-compliant. The outcome has been a new tax morale approach (Webb et al., 2009, 2013; Williams, 2018; Williams et al., 2017). Grounded in institutional theory (North, 1990), this approach views tax noncompliance to result from formal institutional failings that lead tax payers to view tax noncompliance as acceptable (Cummings et al., 2009; Kirchler, 2007; Murphy, 2008; Torgler, 2007, 2012; Williams and Horodnic, 2015a,b,

\footnotetext{
The University of Sheffield - Management School
} 


\section{Articles}

$2016 a, b)$. The solution is therefore to improve what is termed tax morale, namely the intrinsic motivation to pay taxes (Torgler, 2012; Torgler and Schneider, 2007a). Until now, however, most studies of tax morale have focused upon citizens when considering the level of tax morale. They have not focused upon the tax morale of entrepreneurs, or which formal institutional failings need to be resolved to improve the tax morale of entrepreneurs. This paper seeks to fill these lacunae.

In consequence, this paper advances the new tax morale approach in three ways. Firstly, and empirically, it focuses upon the tax morale of entrepreneurs and how the level of tax morale varies across different types of entrepreneur. Secondly, we advance the theoretical basis of this new institutional theory by identifying more precisely the formal institutional failings that lead to low tax morale, and which therefore lead to tax non-compliance. Third and finally, and from a policy viewpoint, we discuss some of the formal institutional failings that need to be solved to prevent tax non-compliance.

To achieve this, section 2 reviews the emergent literature explaining tax noncompliance from a tax morale perspective to formulate hypotheses regarding not only the varying level of tax morale across different types of entrepreneur, but also the formal institutional failings that lead to lower levels of tax morale. To test these, section 3 then reports the data used, namely a 2015 survey of entrepreneurs in Bulgaria, involving 456 face-to-face interviews. Section 4 then reports the findings, while section 5 summarises the implications for theory and policy.

\section{Tax non-compliance and tax morale: literature review and hypotheses development}

For nearly fifty years, a rational economic actor approach has been dominant when
An Institutional Theory of Tax Non-Compliance in

Bulgaria: a Tax Morale Approach

explaining tax non-compliance. Originally proposed in a seminal paper by Allingham and Sandmo (1972), this asserts that tax payers are non-compliant when the benefits of doing so are greater than the expected costs of being detected and fined. To tackle tax noncompliance, most governments therefore focus on increasing the actual or perceived probability of detection and level of penalties (e.g., Horodnic, 2018; ILO, 2017; Williams, 2014, 2018; Williams and Puts, 2017). This is also the case in Bulgaria. Between 2005 and 2009 , for example, a review of the measures used to tackle tax non-compliance in Bulgaria finds that of the 222 measures used, the majority were focused on improving the risk of detection and creating tougher sanctions (CSD, 2009).

Despite the dominance of this rational economic actor approach, the evidence of its effectiveness at reducing non-compliance is less than conclusive. Although some commentators find that increasing fines and the risk of detection reduces tax noncompliance (Feld and Frey 2002; Mas'ud et al., 2015; Mazzolini et al., 2017), others find no significant association (Shaw et al, 2008; Williams and Franic, 2015, 2016), and yet others that increasing the actual or perceived fines and risks of detection results in higher levels of tax non-compliance (Hofmann et al., 2017; Kaplanoglou and Rapano, 2015; Murphy, 2005, 2008; Murphy and Harris, 2007). Indeed, the major criticism of this rational economic actor approach is that many tax payers remain compliant even when benefits of being noncompliant far outweigh the costs, suggesting that they should be non-compliant (Kirchler, 2007; Murphy, 2008; Murphy and Harris, 2007; Williams and Krasniqi, 2017, 2018).

To explain why tax payers are compliant even when the pay-off is greater than the costs, a "tax morale" approach has emerged. This asserts that tax payers have a greater 


\section{Articles}

likelihood of being tax non-compliant if they possess low tax morale, by which is meant a low intrinsic motivation to pay taxes (Torgler, 2007a, 2012). To provide a theoretical basis to this conceptualisation, a loose group of scholars have drawn inspiration from institutional theory (North, 1990). This views institutions as the rules of the game. All societies have both formal institutions, which are the laws and regulations that define the legal rules of the game, as well as informal institutions, which are the "socially shared rules, usually unwritten, that are created, communicated and enforced outside of officially sanctioned channels" (Helmke and Levitsky, 2004: 727). When these are fully aligned, tax non-compliance will not occur, except unintentionally, because the values, norms and beliefs of tax payers will be fully aligned with the formal rules of the game. However, when the formal and informal institutions/rules of the game are not aligned, which can be measured by the level of tax morale, then engagement in tax non-compliance will become more prevalent (Williams, 2018).

Indeed, this non-alignment of formal and informal institutions is widely recognised in Bulgaria. Surveys repeatedly point to a lack of trust in government due to, for example, public sector corruption and an inefficient judiciary as key reasons for tax non-compliance (European Commission, 2012; Goev, 2009). Indeed, the World Economic Forum's Global Competitiveness Report ranks Bulgaria 112 out of 148 countries in terms of the quality of its institutions in 2014, with particularly low scores given to public trust in politicians (1.9 out of 7), favouritism in decisions of government officials (2.1 out of 7 ) and judicial independence (2.3) (World Economic Forum, 2014). The widely shown consequence is that tax non-compliance, although illegal from the viewpoint of formal institutions, enjoys high levels of social legitimacy in Bulgaria (BICA, 2011; CSD, 2013).

Indeed, lower levels of tax morale have been found to be significantly associated with higher levels of tax non-compliance (Brink and Porcano, 2016; Dell'Anno, 2009; Horodnic and Williams, 2016; Lima and Zaklan, 2008; Lisi, 2015; Ostapenko and Williams, 2016; Stark and Kirchler, 2017; Sumartaya and Hafidiah, 2014; Torgler, 2004a; Torgler and Schaffner, 2007; Torgler et al., 2008; Williams and Horodnic, 2015a,b,c,d,e, 2016a,b, 2017a; Windebank and Horodnic, 2017). Indeed, a strong negative correlation has been identified between tax morale and tax non-compliance with Pearson $r$ values between -.46 and -.66 (Alm and Torgler, 2006; Torgler, 2011). For example, Torgler (2011) reveals how in postsocialist societies a one unit decrease in tax morale in a 20 percentage points increase in tax non-compliance.

Until now, however, most of these studies have been on tax payers in general. There has been an absence of studies on the tax morale of entrepreneurs. Studies on tax payers display that tax morale varies by socio-demographic characteristics such as age, gender, employment status, religiosity, marital status and social class (for a review, see Horodnic, 2018). However, there has been until now no data on whether tax morale varies by the characteristics of entrepreneurs such as the sector in which they work, their number of employees, and the legal status of their business. Although there is data on how entrepreneurs have lower tax morale than employees (e.g., Alm and Torgler, 2006; Torgler, 2007), and studies have revealed that tax non-compliance varies by sector, firm size, and so forth (e.g., Williams et al., 2017), no studies have sought to evaluate how the tax morale of entrepreneurs varies across these characteristics. To evaluate this, therefore, the following hypotheses can be tested: 


\section{Articles}

Sector hypothesis (H1): Tax morale will be lower in some sectors than others.

Firm size hypothesis(H2): entrepreneurs operating as sole traders or with 1-9 employees are more likely to have lower tax morale than those operating businesses with more employees.

Legal status hypothesis

(H3): entrepreneurs operating as sole proprietors are more likely to have lower tax morale than those operating limited companies.

Firm age hypothesis (H4): entrepreneurs of younger firms are more likely to have a lower tax morale than entrepreneurs in older business ventures.

Urban hypothesis (H5): entrepreneurs operating in larger urban areas are more likely to have a lower tax morale than entrepreneurs operating in rural areas.

VAT hypothesis (H6): entrepreneurs who are not VAT registered are more likely to have a lower tax morale than entrepreneurs who are VAT registered.

What, therefore, causes low levels of tax morale among some entrepreneurs than others? When analysing citizens, rather than entrepreneurs, numerous studies have found that the level of tax morale depends on whether citizens perceive the tax system as fair, or taxes to be inappropriately used by government (Alasfour et al., 2016; Alm and Gomez, 2008; Çevik, 2016; Cummings et al., 2009; Cyan et al., 2016; Frey, 2003; Niesiobędzka, 2014; Torgler and Schaffner, 2007; Torgler et al., 2008; Vythelingum et al., 2017). For example, tax morale is low when citizens view there to be resource misallocations and inefficiencies due to state capture. This is where firms or groups of firms influence the formulation of laws and other government policies to their own advantage through illicit or non-transparent means (Fries et al., 2003). The result is that they receive preferential treatment and state resources
An Institutional Theory of Tax Non-Compliance in

Bulgaria: a Tax Morale Approach

are diverted towards them. For those not part of these elites who capture the resources of the state, the result is burdensome taxes, and relatively fewer public services in return for the taxes and social contributions they pay (De Soto, 1989; Siqueira et al., 2016; Williams et al., 2016). In nations where state capture is more prevalent, in consequence, citizens have lower levels of tax morale because the citizens feel cheated (Chan et al., 2018; Saitta, 2017; Torgler, 2001; Torgler et al., 2007b). In Bulgaria, the widespread perception is that the laws and regulations of formal institutions are made for the benefit of the ruling classes who are viewed as allegedly extracting money from the taxes paid for their own personal gain. The result is that many citizens are unwilling to pay their taxes due to the perceived unfairness of the system and their belief that any taxes paid will not benefit them in terms of schools, hospitals and so forth but instead will find its way into the pockets of the ruling classes (Dzhekova and Williams, 2014). To start to evaluate whether this is also the case when entrepreneurs are analysed, the following hypothesis can be tested:

Distributive fairness hypothesis (H7): the lower is the perception of entrepreneurs that they receive sufficient in return for the taxes they pay, the lower is the level of tax morale.

The level of tax morale is also related to the perceived quality of public services (Williams, 2018; Williams and Horodnic, 2017a; Williams and Martinez, 2017), such as the perceived effectiveness of government spending (Alasfour et al., 2016; Barone and Mocetti, 2011; Molero and Pujol, 2012; Sipos, 2015; Vythelingum et al., 2017). This can be measured by examining the perceived presence of public sector corruption (Khan and Quaddus, 2015; Round et al., 2008; Tonoyan et al., 2010), by which is meant the 'misuse of public office for private gain' 


\section{Articles}

(Svensson, 2005). This occurs in relation to entrepreneurs when government officials ask for bribes (e.g., a portion of a given contract) in return for a service. This service might be speeding up the approval process for an operating license, not writing a negative outcome for a workplace inspection, or helping entrepreneurs avoid delays in some other regulatory process such as the granting of a construction permit. Where public sector corruption prevails, therefore, tax morale is likely to be lower. This is widely perceived to be the case in Bulgaria (Dzhekova and Williams, 2014). To evaluate this, the following hypothesis can be tested:

Public sector corruption hypothesis (H8): the greater the perceived level of public corruption, the lower is the level of tax morale.

A further and final formal institutional failing here reviewed is the perceived and/or actual instability and uncertainty of the formal rules. Formal institutional instability and uncertainty results when there are continuous changes in the laws and regulations (Levitsky and Murillo, 2009; Williams and Shahid, 2016). This is often the case in many transition economies where entrepreneurs and enterprises are subjected to continuous ongoing alterations in the formal rules, and therefore do not expect the rules that apply today to remain the same in the future. For example, citizens and entrepreneurs in such countries see little point in paying compulsory social insurance contributions so that they can claim unemployment benefits or pensions in the future, because they have little reason to believe that when they wish to benefit, the same rules will apply. This lack of perceived permanency of the formal rules is a major problem for governments. It leads to low levels of tax morale. Indeed, this instability of the formal rules is widely recognised in Bulgaria, with 69 changes having occurred in the tax laws and regulations in just five years (Dzhekova and Williams, 2014). A further related issue is that when the perception is that the formal rules are not indigenous to the nation but are imposed from the outside, such as by supra-national institutions, tax morale will again be much lower (see Williams et al., 2013). Indeed, in such situations, it is perhaps unsurprising that populations and entrepreneurs look beyond the formal laws and regulations to the informal institutions for a more permanent shared set of norms and rules in relation to what is acceptable and what is not to govern and structure their economic activities instead of relying on formal laws and regulations (London et al., 2014; Mair et al., 2012), which can be very fluid and temporary. To start to evaluate this, the following hypothesis can be tested:

Instability of formal institutions hypothesis (H9): the greater is the perceived political instability, the lower is the level of tax morale.

\section{Data and Variables}

\subsection{Data}

To evaluate these hypotheses on the tax morale of different entrepreneurs, and the determinants of low tax morale, data is reported from a representative survey of entrepreneurs conducted in 2015 in Bulgaria, a country where the informal economy is one of the largest in Europe (Williams et al., 2017b) and there is found to be a low level of tax morale among its citizens (Williams and Franic, 2015, 2016). The sampling methodology ensured that the samples are proportionate to the universe in Bulgaria with respect to firm size, region and sector. The owners or managers of a representative sample of 456 businesses were surveyed.

Given the sensitive nature of the topic, it was necessary to establish a rapport with 


\section{Articles}

the interviewees. The survey in consequence started with non-sensitive questions about their satisfaction with the business environment. This was then followed by questions on the acceptability of various noncompliant behaviours and only after this, were questions asked on whether they consider themselves affected by businesses using informal practices and their own participation in informal economic practices. Reviewing the responses of the interviewers in relation to the perceived reliability of the interviews that were conducted, interviewers reported excellent or fair cooperation in 94 per cent of interviews with entrepreneurs. The interviewer stated that cooperation was bad, or the interviewer did not assess the reliability of the interviews, in just 1 per cent of interviews.

\subsection{Variables}

To evaluate the hypotheses, ordered logit regression analysis has been here used. The dependent variable is a categorical variable showing the level of tax morale. To measure the level of tax morale of entrepreneurs, the following question was asked: To what extent do you agree that underreporting annual revenue or turnover in order to evade taxes is acceptable. The responses were given on a 10-point Likert scale, where 1 means completely disagree, and 10 means completely agree. In this paper, the 10-point scale has been recoded into a four point scale (Torgler, 2004; Torgler and Schneider, 2009): value $1=$ low tax morale (responses from 4 through 10, due to the low number of responses); value 2 = middle lower tax morale (response 3); value 3 = middle upper tax morale (response 2); and value 4=high tax morale (response 1 "completely disagree").

To test if and how the level of tax morale varies across entrepreneurs, a series of firmlevel independent variables derived from previous studies analysing the likelihood of participation in tax non-compliance (Ali and
An Institutional Theory of Tax Non-Compliance in

Bulgaria: a Tax Morale Approach

Najman, 2018; Hudson et al., 2012; Putniņš and Sauka, 2017; Putniņš et al., 2018; Williams and Horodnic, 2017a, b) are used, as detailed below:

- Sector: A categorical variable describing the main activity of the company: $1=$ agriculture, 2 = hotels and restaurants, 3 = services, 4 = construction, $5=$ transport and communications, $6=$ trade, $7=$ retail, 8 = industry, 9 = health, $10=$ other.

- Number of employees: A categorical variable describing the total number of currently employed people in the observed company (excluding owners and partners): $1=$ sole traders and micro (0-9 employees), 2 = small (10-49 employees), 3 = medium and large (50+ employees).

- Legal Status: A categorical variable describing the legal status of observed company: 1 = sole proprietorship, 2 = private limited company, limited by shares (LTD.), 3 = public Ltd Company (PLC), 4 = other.

- Age business: A categorical variable showing how many years has the observed company been trading (this includes under all ownerships and all legal statuses): 1 = less than 5 years, 2 =6-10 years, $3=11-20$ years, $4=$ more than 20 years.

- Business locality: A categorical variable describing in what kind of locality does the observed company carry out its main activity: 1 = the capital, 2 = big city (regional centre), 3 = small town, $4=$ village or rural area, $5=$ the entire country, $6=$ both inside the country and outside the country, or outside the country only.

- Vat registered: A dummy variable describing whether the respondent's company is VAT registered: $0=$ no, $1=$ yes.

- The key independent variables used to evaluate each hypothesis about 


\section{Articles}

the determinants of low tax morale, meanwhile, are the following:

- Tax fairness: A categorical variable recorded using the following survey question - To what extent do you agree with the statements that the state does not give businesses enough in return for the taxes they pay. This variable is measured on a 10-point Likert scale, 1 means completely disagree, 10 means completely agree.

- Corruption as an obstacle to the current operations of the companies. A categorical variable recorded using the following survey question - To what degree is corruption an obstacle to the current operations of the companies: value $1=$ very severe obstacle, value $2=$ major obstacle, value $3=$ moderate obstacle, value $4=$ minor obstacle, value $5=$ no obstacle.

- Political instability as an obstacle to the current operations of the companies. A categorical variable recorded using the following survey question - To what degree is political instability an obstacle to the current operations of the companies: value $1=$ very severe obstacle, value $2=$ major obstacle, value $3=$ moderate obstacle, value $4=$ minor obstacle, value $5=$ no obstacle.

For the descriptive analysis below, the crude data for each variable is reported to provide an accurate description and to minimise any bias that would be encountered by excluding those entrepreneurs who did not provide responses to all the variables in the analysis but provided responses for some questions. In the regression analysis, however, only those respondents for which data on each variable was available for each model were analysed due to the technical requirements of this type of analysis. Answers of "don't know" and "refusal" were eliminated in all estimations. Accordingly, an ordered logit model has been used without multiple imputations.

\section{Results}

Table 1 presents the descriptive results of the level of tax morale of entrepreneurs in Bulgaria. This reveals that overall $50.6 \%$ have a low level of tax morale, strongly agreeing that it is acceptable to underreport annual revenue or turnover to evade taxes, $10.3 \%$ have a lower middle tax morale, $11.2 \%$ an upper middle tax morale and just $28.0 \%$ a high tax morale, completely disagreeing that it is acceptable to underreport annual revenue or turnover to evade taxes. However, the level of tax morale of entrepreneurs varies across different groups according to various firmlevel characteristics (see Table 1).

Table 1. Distribution of tax morale in Bulgaria, \% of entrepreneurs

\begin{tabular}{lllll}
\hline & $\begin{array}{l}\text { Low tax } \\
\text { morale }\end{array}$ & $\begin{array}{l}\text { Mid low } \\
\text { tax morale }\end{array}$ & $\begin{array}{l}\text { Mid high } \\
\text { tax morale }\end{array}$ & $\begin{array}{l}\text { High tax } \\
\text { morale }\end{array}$ \\
\hline Total & 50.6 & 10.3 & 11.2 & 28.0 \\
\hline Sector & & & & \\
$\quad$ Agriculture & 41.2 & 17.7 & 5.9 & 35.3 \\
$\quad$ Hotels and restaurants & 60.7 & 7.1 & 10.7 & 21.4 \\
$\quad$ Services & 51.9 & 15.4 & 5.8 & 26.9 \\
Construction & 65.4 & 3.9 & 19.2 & 11.5 \\
Transport and communications & 36.0 & 8.0 & 16.0 & 40.0 \\
Trade & 54.4 & 7.6 & 14.1 & 23.9 \\
Retail & 57.8 & 9.4 & 7.8 & 25.0 \\
Industry & 31.3 & 21.9 & 9.4 & 37.5
\end{tabular}




\begin{tabular}{|c|c|c|c|c|}
\hline & $\begin{array}{l}\text { Low tax } \\
\text { morale }\end{array}$ & $\begin{array}{l}\text { Mid low } \\
\text { tax morale }\end{array}$ & $\begin{array}{l}\text { Mid high } \\
\text { tax morale }\end{array}$ & $\begin{array}{l}\text { High tax } \\
\text { morale }\end{array}$ \\
\hline Other & 48.7 & 6.6 & 13.2 & 31.6 \\
\hline \multicolumn{5}{|l|}{ Number of employees } \\
\hline Sole trader & 33.3 & 9.1 & 18.2 & 39.4 \\
\hline Micro (1-9 employees) & 53.8 & 10.5 & 9.6 & 26.1 \\
\hline Small (10-49 employees) & 36.0 & 4.0 & 20.0 & 40.0 \\
\hline Medium and large (50+ employees) & 38.9 & 16.7 & 16.7 & 27.8 \\
\hline \multicolumn{5}{|l|}{ Legal status } \\
\hline Sole proprietorship & 51.7 & 13.8 & 10.3 & 24.1 \\
\hline Private limited company, limited by shares (LTD.) & 50.0 & 8.4 & 11.9 & 29.7 \\
\hline Public Ltd Company (PLC) & 58.3 & 8.3 & 0.0 & 33.3 \\
\hline Other & 50.0 & 25.0 & 16.7 & 8.3 \\
\hline \multicolumn{5}{|l|}{ Firm age } \\
\hline Less than 5 years & 55.0 & 10.0 & 10.8 & 24.2 \\
\hline $6-10$ years & 50.0 & 10.5 & 12.1 & 27.4 \\
\hline $11-20$ years & 53.2 & 11.9 & 10.3 & 24.6 \\
\hline More than 20 years & 40.8 & 6.1 & 12.2 & 40.8 \\
\hline \multicolumn{5}{|l|}{ Business locality } \\
\hline The capital & 55.3 & 7.0 & 9.7 & 28.1 \\
\hline Big city (regional centre) & 47.0 & 10.7 & 11.1 & 31.2 \\
\hline Small town & 58.8 & 8.8 & 11.8 & 20.6 \\
\hline Village or rural area & 58.3 & 16.7 & 16.7 & 8.3 \\
\hline The entire country & 48.2 & 18.5 & 7.4 & 25.9 \\
\hline $\begin{array}{l}\text { Both inside the country and outside the country, or outside the } \\
\text { country only }\end{array}$ & 57.1 & 14.3 & 28.6 & 0.0 \\
\hline \multicolumn{5}{|l|}{ Vat registered } \\
\hline No & 57.5 & 10.0 & 10.0 & 22.5 \\
\hline Yes & 43.6 & 10.8 & 12.4 & 33.2 \\
\hline \multicolumn{5}{|l|}{$\begin{array}{l}\text { The state does not give businesses enough in return for the taxes } \\
\text { they pay }\end{array}$} \\
\hline Completely disagree & 47.1 & 5.9 & 11.8 & 35.3 \\
\hline 2 and 3 & 28.6 & 10.7 & 25.0 & 35.7 \\
\hline 4 and 5 & 44.6 & 21.4 & 8.9 & 25.0 \\
\hline 6 and 7 & 52.7 & 10.8 & 8.1 & 28.4 \\
\hline 8 and 9 & 64.7 & 9.8 & 6.9 & 18.6 \\
\hline Completely agree & 52.9 & 5.8 & 10.6 & 30.8 \\
\hline \multicolumn{5}{|l|}{$\begin{array}{l}\text { Corruption as an obstacle to the current operations of the } \\
\text { companies }\end{array}$} \\
\hline Very severe obstacle & 56.1 & 7.2 & 9.4 & 27.3 \\
\hline Major obstacle & 53.4 & 14.6 & 15.5 & 16.5 \\
\hline Moderate obstacle & 48.6 & 12.9 & 14.3 & 24.3 \\
\hline Minor obstacle & 45.2 & 7.1 & 9.5 & 38.1 \\
\hline No obstacle & 34.1 & 11.4 & 4.6 & 50.0 \\
\hline \multicolumn{5}{|l|}{$\begin{array}{l}\text { Political instability as an obstacle to the current operations of the } \\
\text { companies }\end{array}$} \\
\hline Very severe obstacle & 60.4 & 7.7 & 8.8 & 23.1 \\
\hline Major obstacle & 51.1 & 8.0 & 18.2 & 22.7 \\
\hline Moderate obstacle & 47.2 & 17.0 & 13.2 & 22.6 \\
\hline Minor obstacle & 54.4 & 8.7 & 4.4 & 32.6 \\
\hline No obstacle & 41.4 & 7.1 & 8.6 & 42.9 \\
\hline
\end{tabular}

Source: Authors' own work based on the representative survey in Bulgaria 


\section{Articles}

Commencing with how tax morale varies by the sector in which entrepreneurs operate, the finding is that a larger proportion of entrepreneurs in agriculture, the health sector, manufacturing industry and transport and communications have a high tax morale, while higher proportions have a low tax morale in the construction industry, hotels and restaurants sector, retail and trade sectors, and services. Similarly, a higher proportion of entrepreneurs operating micro-enterprises have a low tax morale. However, there appears to be little marked variation according to the legal status of the business venture that they operate. It is the case, nevertheless, that entrepreneurs operating enterprises older than 20 years tend to have a higher tax morale than those operating younger enterprises, as do a greater proportion have low tax morale who are operating businesses in the capital city of Sofia and small towns and rural areas, as do those who are not registered for VAT have a lower tax morale.

There is, however, some association between the satisfaction of entrepreneurs with the state giving businesses enough in return for the taxes they pay, and their level of tax morale. Those completely agreeing that the state does not give businesses enough in return for the taxes they pay have lower tax morale, while those believing that the state does give businesses enough in return have higher tax morale. There also appears to be a close association between perceptions of corruption and the level of tax morale of entrepreneurs. Those viewing corruption as more prevalent have lower tax morale. Some
$56.1 \%$ of those perceiving corruption as a very severe obstacle have a low tax morale but just $34.1 \%$ of those perceiving corruption as no obstacle. Similarly, just $27.3 \%$ of those who perceive corruption as a very severe obstacle have a high tax morale but $50 \%$ of who perceive corruption as no obstacle. Finally, $60.4 \%$ of those entrepreneurs who perceive political instability as a very severe obstacle to the current operations of their business have a low tax morale but only $41.4 \%$ of those who do not perceive political instability as an obstacle. And similarly, 23.1\% of those entrepreneurs who perceive political instability as a very severe obstacle to the current operations of their business have a high tax morale but $42.9 \%$ of those who do not perceive political instability as an obstacle.

The shortcoming of these descriptive statistics is that they do not take account of, and hold constant, other variables which may influence these correlations. To do this, Table 2 therefore presents an ordered logit regression analysis. This adopts a staged approach. Model 1 consider the variations in the level of tax morale of entrepreneurs across various firm-level variables. To evaluate the various formal institutional determinants that lead to low tax morale, model 2 then adds in the variable of whether the state gives businesses enough in return for the taxes they pay, model 3 their views on whether public sector corruption is an obstacle to the current operations of their business, and model 4 their views on whether political instability is an obstacle to the current operations of their business. 


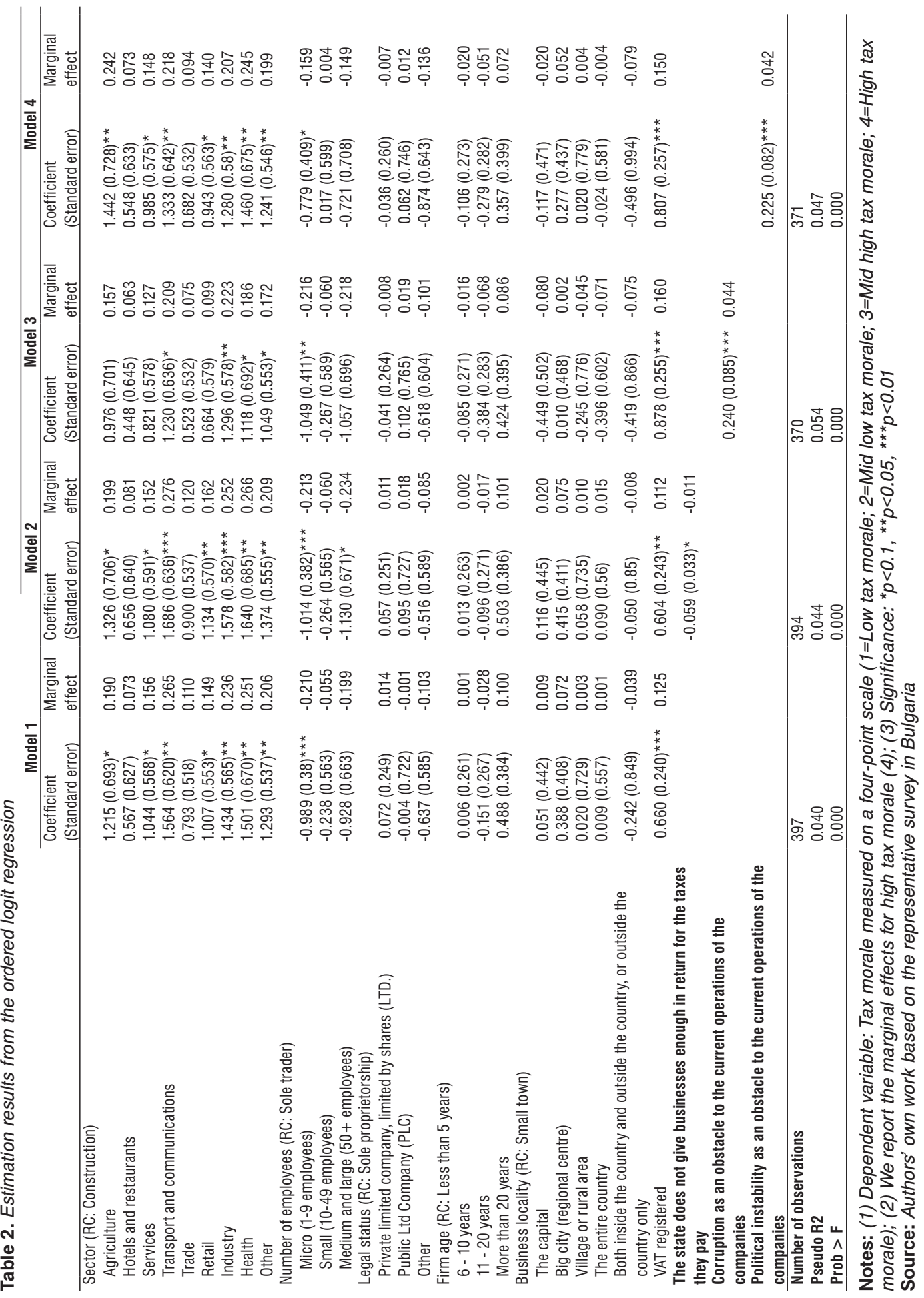




\section{Articles}

Starting with how the level of tax morale varies across entrepreneurs operating different types of business, model 1 in Table 2 reveals that there are some significant sectoral variations. Compared with the tax morale of entrepreneurs operating in the construction sector, entrepreneurs have a significantly higher tax morale who operate in the agriculture, services, transport and communications, retailing, manufacturing industry, health and other sectors (confirming hypothesis $\mathrm{H} 1$ ). Moreover, there are also variations in entrepreneurs' tax morale by the number of employees they employ. Those operating micro-enterprises (with 1-9 employees) have a significantly lower tax morale than those who are sole traders. This, therefore, requires a refinement of hypothesis $\mathrm{H} 2$. It is entrepreneurs operating micro-enterprises with 1-9 employees have a lower tax morale than sole traders. Interestingly, however, when other variables are held constant, there is no difference in the tax morale of entrepreneurs by the legal status of their business venture (refuting hypothesis H3). Neither are there significant variations by age of the business (refuting hypothesis H4) or the type of locality in which the business operates (refuting hypothesis $\mathrm{H} 5)$. However, there are significant variations by whether they have registered for VAT or not. Those entrepreneurs who have registered their businesses for VAT have a higher tax morale than those who have not (confirming hypothesis $\mathrm{H6}$ ).

To start to evaluate the various formal institutional determinants that lead to this non-alignment of entrepreneurs' views with the formal rules $_{2}$ model 2 in Table 2 adds in the variable of whether they view the state as giving businesses enough in return for the taxes they pay. The significance and direction of association remains the same for all the firm-level characteristics in model 1 . The additional finding is that there is a significant association between the tax morale of entrepreneurs and their view on whether the state gives businesses enough in return for the taxes they pay. Those who not believe that the state gives businesses enough in return have significantly lower tax morale (confirming Hypothesis H7). An increase by one unit in the perception that the state does not give businesses enough in return for the taxes they pay decreases by 1.1 percentage points the proportion of entrepreneurs indicating the highest level of tax morale.

Model 3 in Table 2, meanwhile, examines their views on whether public sector corruption is an obstacle to the current operations of their business and whether this is associated with their level of tax morale. The finding is that the greater the perceived level of public corruption, the lower is the level of tax morale (confirming Hypothesis H8). An increase by one unit in an entrepreneur's perception that corruption is an obstacle to their operations decreases by 4.4 percentage points the proportion of entrepreneurs indicating the highest level of tax morale.

Finally, model 4 in Table 2 explores whether perceived political instability is associated with the tax morale of entrepreneurs. The finding is that the greater is the perceived political instability, the lower is the level of tax morale (confirming Hypothesis H9). An increase by one unit in the perception of entrepreneurs that political instability is an obstacle to their current operations decreases by 4.2 percentage points the proportion of entrepreneurs indicating the highest level of tax morale.

\section{Discussion and Conclusions}

This paper has evaluated a new tax morale approach, based on institutionalist theory, which argues that formal institutional failures lead to the emergence of lower 


\section{Articles}

tax morale amongst entrepreneurs, which in turn leads to the prevalence of tax noncompliance. Reporting face-to-face interviews with a nationally representative sample of 456 entrepreneurs in Bulgaria, it is revealed not only that the tax morale of entrepreneurs varies by sector and firm size, but also that the formal institutional failings significantly associated with low tax morale include a perceived lack of tax fairness, corruption and political instability.

In terms of the theoretical implications, therefore, this paper makes three advances. Firstly, most studies explaining tax noncompliance from this tax morale approach have focused upon citizens or employees' levels of tax morale. Few have evaluated the tax morale of entrepreneurs. This paper has filled this lacuna. Secondly, it has revealed that there are indeed variations in the levels of tax morale of entrepreneurs according to the sector in which they operate and the number of employees they employ. Third and finally, and importantly for further advancing institutional theory, some of the formal institutional failures that lead to the lower tax morale of some entrepreneurs have been identified. There is a significant association between the tax morale of entrepreneurs and their perceptions of tax fairness, public sector corruption and instability in the formal institutions.

Turning to the implications for policy, this paper reveals that at a minimum, the dominant rational economic actor policy approach, which seeks to increase the risks of detection and penalties, should be complemented with a policy approach that seeks to improve tax morale. To achieve this, the first approach is to improve the tax morale of entrepreneurs using tax education and awareness raising campaigns (e.g., by providing information about the benefits of being compliant, and showing the public
An Institutional Theory of Tax Non-Compliance in

Bulgaria: a Tax Morale Approach

goods and services received for the taxes paid). It is arguable, nevertheless, that the tax morale of entrepreneurs will not change until there are alterations in the formal institutions. Secondly, therefore, formal institutions need to be improved. As the ordered logit regression analysis in this paper reveals, this requires, at a minimum, improvements in tax fairness, reduced public sector corruption and greater stability in the formal institutions and rules of the game.

Despite these clear implications for theory and policy, this paper nevertheless has its limitations. Firstly, it reports results for only one country. Future research, therefore, needs to evaluate whether similar significant associations are identified when conducting surveys of entrepreneurs in other countries. Secondly, although this study reveals that tax morale is affected by formal institutional failings, it only uncovers some of the formal institutional failings that lead to lower tax morale. Future quantitative as well as in-depth qualitative research, therefore, is needed to evaluate systematically a wider range of formal institutional failings that might lead to lower tax morale, so that government can pursue more targeted policy measures to improve the level of tax morale and therefore tax non-compliance.

In sum, this paper has revealed the importance of the tax morale approach grounded in institutional theory when explaining and tackling tax non-compliance in Bulgaria. If this paper stimulates similar studies in other nations and more in-depth research on the formal institutional failings that lead to lower tax morale, then this paper will have fulfilled a primary intention. If this then leads to changes in the policy approach adopted for tackling tax non-compliance, with greater emphasis put on addressing the low levels of tax morale that lead to higher 


\section{Articles}

levels of tax non-compliance, then it will have fulfilled its fuller intention.

\section{References}

Alasfour, F., Samy, M. and Bampton, R., 2016. The determinants of tax morale and tax compliance: evidence from Jordan, in $\mathrm{J}$. Hasseldine (ed.), Advances in Taxation, Bingley: Emerald, 125-171.

Ali, N. and Najman, B., 2018. Informal competition, firm productivity and policy reforms in Egypt in I.A. Horodnic, P. Rodgers, C.C. Williams and L. Momtazian (Eds.), The Informal Economy Exploring Drivers and Practices, London: Routledge, 229-254.

Allingham, M.G. and Sandmo, A., 1972. Income tax evasion: a theoretical analysis. Journal of Public Economics, 1(3-4), pp. 323-338.

Alm, J. and Gomez, J.L., 2008. Social capital and tax morale in Spain. Economic Analysis and Policy, 38(1), pp.73-87.

Alm, J. and Torgler, B., 2006. Culture differences and tax morale in the United States and in Europe. Journal of Economic Psychology, 27(2), pp. 224-246.

Barone, G. and Mocetti, S., 2011. Tax morale and public spending inefficiency. International Tax and Public Finance, 18(6), pp.724-749.

BICA, 2011. Дokıаg за Основните ПреguзBukameлства за Диагностика, ОграничаВане и ПреВенция на Неформалната Икономика [Report on the Key Challenges to the Diagnosis, Restriction and Prevention of the Informal Economy], Sofia: BICA.

Brink, W.D. and Porcano, T.M., 2016. The impact of culture and economic structure on tax morale and tax evasion: a country-level analysis using SEM, in J. Hasseldine (ed.), Advances in Taxation, Bingley: Emerald, Bingley, 87-123.

Center for the Study of Democracy, 2009. Policies to counter the effects of the economic crisis: hidden economy dynamics 2009. Policy Brief No. 20, CSD, Sofia.
Center for the Study of Democracy, 2013. The hidden economy in Bulgaria. Policy Brief No. 37, CSD, Sofia.

Çevik, S., 2016. Tax morale and tax compliance in socio-political context, in M. Aydin and S.S. Tan (Eds.), Political Economy of Taxation, Istanbul: IJOPEC, 37-57.

Chan, H.F., Supriyadi, M.W. and Torgler, B., 2018. Trust and tax morale, in E.M. Uslaner (ed.), The Oxford Handbook of Social and Political Trust, Oxford: Oxford University Press, 42-81.

Cummings, R.G., Martinez-Vazquez, J., McKee, M. and Torgler, B., 2009. Tax morale affects tax compliance: evidence from surveys and an artefactual field experiment. Journal of Economic Behavior and Organization, 70(3), pp. 447-457.

Cyan, M.R., Koumpias, A.M. and MartinezVazquez, J., 2016. The determinants of tax morale in Pakistan. Journal of Asian Economics, 47, pp. 23-34.

De Soto, H., 1989. The Other Path: the economic answer to terrorism. London: Harper and Row.

Dell'Anno, R., 2009. Tax evasion, tax morale and policy maker's effectiveness. The Journal of Socio-Economics, 38(6), pp.988-997.

Dzhekova, R. and Williams, C.C., 2014. Tackling the undeclared economy in Bulgaria: a baseline assessment. Sheffield: GREY Working Paper No. 1, Sheffield University Management School, University of Sheffield.

European Commission, 2012. Report from the Commission to the European Parliament and the Council. On Progress in Bulgaria under the Cooperation and Verification Mechanism. COM(2012) 411 final. Brussels: European Commission.

Feld, L.P. and Frey, B.S., 2004. Illegal, immoral, fattening or what? How deterrence and responsive regulation shape tax morale. Marburg: Working Papers on Economics 


\section{Articles}

200426, Department of Economics, PhilippsUniversität Marburg.

Frey, B.S., 2003. Deterrence and tax morale in the European Union. European Review, 11(3), pp.385-406.

Goev, V., 2009. Estimating the hidden economy in Bulgaria. South-East Europe Review for Labour and Social Affairs, 12(1), pp. 77-93;

Helmke, G. and Levitsky, S., 2004. Informal institutions and comparative politics: a research agenda. Perspectives on Politics, 2(4), pp. 725740.

Hofmann, E., Hartl, B., Gangl, K., HartnerTiefenthaler, M. and Kirchler, E., 2017. Authorities' coercive and legitimate power: the impact on cognitions underlying cooperation. Frontiers in Psychology, 8(5), 156-82.

Horodnic, I.A., 2018. Tax morale and institutional theory: a systematic review. International Journal of Sociology and Social Policy, https://doi.org/10.1108/IJSSP-03-2018 $-0039$

Horodnic, I.A. and Williams, C.C., 2016. An evaluation of the shadow economy in Baltic States: a tax morale perspective. International Journal of Entrepreneurship and Small Business, 28(2-3), pp. 339-358.

Hudson, J., Williams, C.C., Orviska, M. and Nadin, S., 2012. Evaluating the impact of the informal economy on businesses in South East Europe: some lessons from the 2009 World Bank Enterprise Survey. The South-East European Journal of Economics and Business, 7(1), pp.99-110.

ILO, 2017. ILO approach to strategic compliance for labour inspectorates. Geneva: ILO.

Kaplanoglou, G. and Rapanos, V.T., 2015. Why do people evade taxes? New experimental evidence from Greece. Journal of Behavioral and Experimental Economics, 56, pp.21-32.

Khan, E.A. and Quaddus, M., 2015. Examining the influence of business environment on
An Institutional Theory of Tax Non-Compliance in

Bulgaria: a Tax Morale Approach

socioeconomic performance of informal microenterprises: content analysis and partial least square approach. International Journal of Sociology and Social Policy, 35(3/4), pp.273288.

Kirchler, E., 2007. The economic psychology of tax behaviour. Cambridge: Cambridge University Press.

Levitsky, S. and Murillo, M.V., 2009. Variation in institutional strength. Annual Review of Political Science, 12(1), pp.115-133.

Lima, F.W.S. and Zaklan, G., 2008. A multiagent-based approach to tax morale. International Journal of Modern Physics C, 19(12), pp.1797-1808.

Lisi, G., 2015. Tax morale, tax compliance and the optimal tax policy. Economic Analysis and Policy, 45, pp.27-32.

London, T., Esper, H., Grogan-Kaylor, E. and Kistruck, G.M., 2014. Connecting poverty to purchase in informal markets. Strategic Entrepreneurship Journal, 8(1), pp.37-55.

Mair, J., Marti, I. and Ventresca, M., 2012. Building inclusive markets in rural Bangladesh: how intermediaries work institutional voids. Academy of Management Journal, 55, pp.819850.

Mas'ud, A., Manaf, N.A.A. and Saad, N., 2015. Testing assumptions of the "slippery slope framework" using cross-country data: evidence from sub-Saharan Africa. International Journal of Business and Society, 16(3), pp.408-421.

Mazzolini, G., Pagani, L. and Santoro, A., 2017. The deterrence effect of real-world operational tax audits. Milan: DEMS Working Paper Series No. 359, Department of Economics, Management and Statistics, University of Milan-Bicocca.

Molero, J.C. and Pujol, F., 2012. Walking inside the potential tax evader's mind: tax morale does matter. Journal of Business Ethics, 105(2), pp.151-162. 


\section{Articles}

Murphy, K., 2005. Regulating more effectively: the relationship between procedural justice, legitimacy, and tax non-compliance. Journal of Law and Society, 32(4), pp.562-589.

Murphy, K., 2008. Enforcing tax compliance: to punish or persuade? Economic Analysis \& Policy, 38(1), pp.113-135.

Murphy, K. and Harris, N., 2007. Shaming, shame and recidivism: a test of reintegrative shaming theory in the white-collar crime context. The British Journal of Criminology, 47(6), pp.900917.

Niesiobędzka, M., 2014. Relations between procedural fairness, tax morale, institutional trust and tax evasion. Journal of Social Research \& Policy, 5(1), pp.41-52.

North, D.C., 1990. Institutions, Institutional Change and Economic Performance. Cambridge: Cambridge University Press.

Ostapenko, N. and Williams, C.C., 2016. Determinants of entrepreneurs' views on the acceptability of tax evasion and the informal economy in Slovakia and Ukraine: an institutional asymmetry approach. International Journal of Entrepreneurship and Small Business, 28(2/3), pp.42-61.

Putniňš, T. and Sauka, A., 2017. Shadow Economy Index for the Baltic countries 20092016. Riga: Centre for Sustainable Business at Stockholm School of Economics in Riga.

Putniņš, T., Sauka, A. and Davidescu, A.A., 2018. Shadow Economy Index for Moldova and Romania 2015 - 2016. Riga: Centre for Sustainable Business at Stockholm School of Economics in Riga.

Round, J., Williams, C.C. and Rodgers, P., 2008. Corruption in the post-Soviet workplace: the experiences of recent graduates in contemporary Ukraine. Work, Employment \& Society, 22(2), pp.149-166.

Saitta, P., 2017. Practices of subjectivity: the informal economies and the subaltern rebellion.
International Journal of Sociology and Social Policy, 37(7/8), pp. 400-416.

Shaw, J., Slemrod, J. and Whiting, J., 2008. Administration \& Compliance. Oxford: Oxford University Press.

Sipos, A., 2015. Determining factors of taxmorale with special emphasis on the tax revenues of local self-governments. Procedia Economics and Finance, 30, pp.758-767.

Siqueira, A.C.O., Webb, J.W. and Bruton, G.D., 2016. Informal Entrepreneurship and Industry Conditions. Entrepreneurship Theory and Practice, 40(1), pp. 177-200.

Stark, J.A. and Kirchler, E., 2017. Inheritance tax compliance - earmarking with normative value principles. International Journal of Sociology and Social Policy, 37(7/8), pp. 452-467.

Sumartaya, D. and Hafidiah, A., 2014. The influence of taxpayer's awareness and tax morale toward tax evasion. International Journal of Business, Economics and Law, 5(1), pp.60-68.

Svensson, J., 2005. Eight questions about corruption. Journal of Economic Perspectives, 19, pp.19-42.

Tonoyan, V., Strohmeyer, R., Habib, M. and Perlitz, M., 2010. Corruption and entrepreneurship: how formal and informal institutions shape small firm behaviour in transition and mature market economies. Entrepreneurship Theory and Practice, 34(5), pp.803-831.

Torgler, B., 2001. What do we know about tax morale and tax compliance? International Review of Economics and Business, 48(3), pp.395-419.

Torgler, B., 2004. Tax morale in Asian countries. Journal of Asian Economics, 15, pp. 237-266.

Torgler, B., 2007. Tax compliance and morale. a theoretical and empirical analysis. Cheltenham: Edward Elgar.

Torgler, B., 2011. Tax morale and compliance review of evidence and case studies for Europe. Washington DC: Policy Research Working Paper 


\section{Articles}

5922, The World Bank, Europe and Central Asia Region.

Torgler, B. and Schaffner. M., 2007. Causes and consequences of tax morale: an empirical investigation. Basel: Working paper no. 2007-11, Center for Research in Economics, Management and the Arts.

Torgler, B. and Schneider, F., 2007. What shapes attitudes toward paying taxes? Evidence from multicultural European countries. Social Science Quarterly, 88(2), pp.443-470.

Torgler, B. and Schneider, F., 2009. The impact of tax morale and institutional quality on the shadow economy. Journal of Economic Psychology, 30(2), pp.228-245.

Torgler, B., Demir, I.C., Macintyre, A. and Schaffner, M., 2008. Causes and consequences of tax morale: an empirical investigation. Economic Analysis and Policy, 38(2), pp. 313339.

Torgler, B., Schaffner, M. and Macintyre, A., 2007. Tax compliance, tax compliance, tax morale, and governance quality. Atlanta: International Studies Program Working Paper 07-27, Andrew Young School of Policy Studies, Georgia State University.

Vythelingum, P., Soondram, H. and Jugurnath, B., 2017. An assessment of tax morale among Mauritian taxpayers. Journal of Accounting and Taxation, 9(1), pp.1-10.

Webb, J.W., Bruton, G.D., Tihanyi, L. and Ireland, R.D., 2013. Research on entrepreneurship in the informal economy: framing a research agenda. Journal of Business Venturing, 28, pp. 598-614. Webb, J.W., Tihanyi, L., Ireland, R.D. and Sirmon, D.G., 2009. You say illegal, I say legitimate: entrepreneurship in the informal economy. Academy of Management Review, 34(3), pp.492510.

Williams, C.C., 2014. Confronting the Shadow Economy: Evaluating Tax Compliance and Behaviour Policies. Cheltenham: Edward Elgar.
An Institutional Theory of Tax Non-Compliance in

Bulgaria: a Tax Morale Approach

Williams, C.C., 2018. Entrepreneurship in the Informal Sector: An Institutional Perspective. London: Routledge.

Williams, C.C. and Franic, J., 2015. Tackling the propensity towards undeclared work: some policy lessons from Croatia. South East European Journal of Economics and Business, 10(1), pp.18-31.

Williams, C.C. and Franic, J., 2016. Beyond a deterrence approach towards the undeclared economy: some lessons from Bulgaria. Journal of Balkan and Near Eastern Studies, 18(1), pp. 90-106.

Williams, C.C. and Horodnic, I.A., 2015a. Evaluating the prevalence of the undeclared economy in Central and Eastern Europe: an institutional asymmetry perspective. European Journal of Industrial Relations, 21(4), pp.389406.

Williams, C.C. and Horodnic, I.A., 2015b. Explaining and tackling the shadow economy in Estonia, Latvia and Lithuania: a tax morale approach. Baltic Journal of Economics, 15(2), pp.81-98.

Williams, C.C. and Horodnic, I.A., 2015c. Tackling the informal economy in Southeast Europe: an institutional approach. Southeast European and Black Sea Studies, 15(4), pp.519539.

Williams, C.C. and Horodnic, I.A., 2015d. Explaining the prevalence of illegitimate wage practices in Southern Europe: an institutional analysis. South European Society and Politics, 20(2), pp.203-221.

Williams, C.C. and Horodnic, I.A., $2015 \mathrm{e}$. Explaining and tackling envelope wages in the Baltic Sea region: an institutional perspective. Baltic Journal of Management, 10(3), pp.295312.

Williams, C.C. and Horodnic, I.A., 2016a. An institutional theory of the informal economy: some lessons from the United Kingdom. 


\section{Articles}

International Journal of Social Economics, 43(7), pp.722-738.

Williams, C.C. and Horodnic, I.A., 2016b. Crosscountry variations in the participation of small businesses in the informal economy: an institutional asymmetry explanation. Journal of Small Business and Enterprise Development, 23(1), pp.3-24.

Williams, C.C. and Horodnic, I.A., 2016c. Tackling the undeclared economy in the European Union: an evaluation of the tax morale approach. Industrial Relations Journal, 47(4), pp.322-340.

Williams, C.C. and Horodnic, I.A., 2017a. Evaluating the illegal employer practice of under-reporting employees' salaries. British Journal of Industrial Relations, 55(1), pp.83-111.

Williams, C.C. and Horodnic, I.A., 2017b. Explaining the informal economy in postcommunist societies: a study of the asymmetry between formal and informal institutions in Romania, in A. Polese, C.C. Williams, I.A. Horodnic and P. Bejakovic (eds.), The Informal Economy in Global Perspective: Varieties of Governance, Basingstoke: Palgrave Macmillan, 117-140.

Williams, C.C. and Krasniqi, B., 2017. Evaluating the individual- and country-level variations in tax morale: evidence from 35 Eurasian countries. Journal of Economic Studies, 44(5), pp.816-832.

Williams, C.C. and Krasniqi, B., 2018. Explaining entrepreneurship in the informal economy: an institutionalist perspective. Journal of Developmental Entrepreneurship, 23(2), 10.1142/ S1084946718500115

Williams, C.C. and Puts, E., 2017. Platform Survey Report: organisational characteristics of enforcement bodies, measures adopted to tackle undeclared work, and the use of databases and digital tools. Brussels: European Commission.

Williams, C.C. and Shahid, M.S., 2016. Informal entrepreneurship and institutional theory: explaining the varying degrees of (in) formalization of entrepreneurs in Pakistan. Entrepreneurship \& Regional Development, 28(1-2), pp.1-25.

Williams, C.C., Franic, J. and Dzhekova, R., 2014. Explaining and tackling the undeclared economy in Bulgaria: an institutional asymmetry perspective. The South-East European Journal of Economics and Business, 9(2), pp. 33-45.

Williams, C.C., Shahid, M. and Martinez-Perez, A., 2016. Determinants of the level of informality of informal micro-enterprises: some evidence from the city of Lahore Pakistan. World Development, 84, pp. 312-325.

Williams, C.C., Martinez-Perez, A. and Kedir, A.M., 2017a. Informal entrepreneurship in developing economies: the impacts of startingup unregistered on firm performance. Entrepreneurship Theory and Practice, 41(5), pp.773-799.

Williams, C.C., Bejakovic, P., Mikulic, D., Franic, J., Kedir, A. and Horodnic, I.A., 2017b. An evaluation of the scale of undeclared work in the European Union and its structural determinants: estimates using the Labour Input Method. Brussels: European Commission.

Windebank, J. and Horodnic, I.A., 2017. Explaining participation in undeclared work in France: lessons for policy evaluation. International Journal of Sociology and Social Policy, 37(3-4), pp.203-217.

World Economic Forum, 2014. Global Competitiveness Report 2014, <http://www. weforum.org/reports/global-competitivenessreport-2013-2014> (accessed 28 June 2018). 